\title{
The scientific literature on Limnoperna fortunei (Dunker 1857) from 1982 to 2012
}

\author{
FABIANA G. BARBOSA \\ National Museum of Natural Sciences/CSIC, C/José Gutiérrez Abascal, 2, 2806, Madrid, Spain \\ Manuscript received on July 10, 2013; accepted for publication on December 10, 2013
}

\begin{abstract}
Limnoperna fortunei (golden mussel) is a freshwater bivalve native to Southeast Asia, but is becoming an invasive species in several aquatic ecosystems in the world. In this study, a scientometric analysis was performed to identify the patterns, trends and gaps of knowledge for this invasive species. A survey of the published literature was conducted using the database of the Thomson Institute for Scientific Information (ISI). A total of 107 papers were surveyed that were published between 1982 and 2012 in 60 journals. The number of papers on L. fortunei over the years has increased, especially within the last eight years of the study period. Argentina, Brazil, and Japan are the countries that contributed the most papers to the literature on invasive bivalve. The majority of papers were field-observational studies. Among some important gaps that need to be addressed are the relatively small number and/or lack of studies conducted in the native countries and in countries invaded by L. fortunei, the lack of internationally collaborative publications in these countries, as well as a low number of internationally collaborative studies.
\end{abstract}

Key words: biological invasions, golden mussel, scientific production, scientometric analysis.

\section{INTRODUCTION}

Invasive species are recognized as a major threat not only to biodiversity (Clavero and GarciaBerthou 2005), but also to economic development (Pimentel et al. 2001, Pejchar and Mooney 2009). To mitigate this global problem, interest in invasive species has grown substantially, mainly in the last decades (Qiu and Chen 2009, Richardson and Pysek 2008, Lowry et al. 2013) and in invasive species in freshwater ecosystems (Strayer 2010).

Among the various taxonomic groups of invaders in freshwater ecosystems, the ecological and economic impact of bivalves is well-documented

E-mail: fabibarbos@gmail.com (see Karatayev et al. 2007a, b and Sousa et al. 2013 to review). Invasive bivalves are considered an aggressive species and a threat to both native diversity and ecosystem functioning (Karatayev et al. 2007b), and in addition to being a threat due to their biofouling activity in structures of industrial and power plants (e.g., hydroelectric power stations, pulp and paper mills, refineries, and water treatment and distribution facilities) (Magara et al. 2001, Elliott et al. 2005, Darrigran et al. 2007, Lucy et al. 2012). Several freshwater invasive bivalve species have been reported worldwide, especially Corbicula fluminalis (Müller 1774), Corbiculla fluminea (Müller 1774), Dreissena bugensis 
(Andrusov 1857), Dreissena polymorpha (Pallas 1771) and Limnoperna fortunei (Dunker 1857) (Karatayev et al. 2007b).

Limnoperna fortunei (Bivalvia, Mytilidae), commonly known as golden mussel, is a freshwater bivalve native to estuaries, lakes, and rivers of southeastern Asia, including Cambodia, China, Indonesia, Korea, Laos, Thailand, and Vietnam (Ricciardi 1998). In 1965, L. fortunei invaded Hong Kong (Morton, 1977), Japan (Kimura 1994) and Taiwan (Ricciardi 1998) in the 1990s. In South America, it was first recorded in 1991 in Bagliardi Beach, Rio de la Plata estuary, Argentina, probably introduced by ballast water from Asian commercial ships (Pastorino et al. 1993). Currently, the distribution of L. fortunei in South America includes estuaries (Darrigran and Pastorino 1995, Brugnoli et al. 2005, Capítoli et al. 2008), lakes, streams, reservoirs, and rivers (Mansur et al. 2003, Oliveira et al. 2006, Boltovskoy et al. 2009) and it can be found in five countries: Argentina (in 1991), Uruguay (in 1994), Paraguay (in 1997), Brazil and Bolivia (in 1998) (Darrigran and Mansur 2006, 2009). This invasive bivalve has also caused serious environmental damage (see Karatayev et al. 2007a to review), as well as having a negative economic impact in South America (Darrigran and Damborenea 2005, Boltovskoy et al. 2006) and Japan (Magara et al. 2001, Matsui et al. 2002).

Scientometric studies can be used to measure scientific progress within a specific topic, country, field, or institution, based on the number of papers published in scientific journals (Van Raan 1997, Hood and Wilson 2001). In a recent scientometric study, Sousa et al. (2013) showed that scientific production on invasive bivalves in freshwater ecosystems has increased steeply in the last years. Therefore, an assessment of the publications on L. fortunei is essential to the scientific progress in the field of the invasive species. In this context, the purpose of this scientometric study was to analyze the literature on Limnoperna fortunei to identify the patterns, trends and knowledge gaps for this invasive species. This present study differs from the study by Sousa et al. (2013) because here were evaluated various traditional scientometric components (e.g., author, citation and journal) and others more specific (e.g., approach employed) that were not evaluated by Sousa et al. (2013). Moreover, some standard indicators (e.g., collaborated publications and coauthorships) were adopted to analyze performance of countries, institutes and researchers (e.g., Liu et al. 2011). Additionally, the results presented here can help researchers manage and prioritize future studies that need to be developed to fill gaps in research on L. fortunei.

\section{MATERIALS AND METHODS}

The survey of the published literature was conducted using the database of the Thomson Institute for Scientific Information (ISI; www.isiknowledge.com) with the keywords "Limnoperna fortunei" or "golden mussel". The search was performed in March 2013 and all papers published until December $31^{\text {st }}, 2012$ were compiled.

Each paper was identified by: (i) the year of publication; (ii) the scientific journal of publication; (iii) the Web of Science subject category(ies) of the journal; (iv) the number of citations; (v) the approach employed (field-experimental, fieldobservational, laboratory-experimental or others, such as, modeling, review, theoretical); (vi) countries of publication; (vii) authors, and (viii) research institutions.

A regression tree (De'Ath and Fabricius 2000) was used to identify possible trends over time for the number of papers on L. fortunei (see Barbosa et al. 2012 for a similar use of this method). The number of papers on L. fortunei was standardized over time by dividing it by the total number of papers in the ISI database in a given year, and multiplying the result by 10,000 . The analysis was conducted using the package rpart (Therneau et al. 2012) in the $R$ environment (R Development Core Team 2013). 
A Generalized Linear Model (family distribution $=$ Poisson) (Crawley 2007) was applied to evaluate the temporal trend of the number of journals and the number of authors per paper. An ANOVA in blocks (Gotelli and Ellison 2012) was used to test the statistical difference between the number of citations among the type of papers (article paper, meeting abstract, proceeding paper, and review), considering the variations from year to year. If significance was detected, the Tukey test was used to determine the statistical differences among the approaches employed $(P<0.05)$. The $t$ test for paired samples (per year; Sokal and Rohlf 1994) was used to test the significance of the difference between the number of articles published as a single country or as an internationally collaborative publication. The analyses were conducted in the $\mathrm{R}$ environment (R Development Core Team 2013).

Collaborations among authors, countries, or research institutions were determined based on the complete count strategy (i.e., each signatory on the papers was treated equally) (Liu et al. 2011). As is common in other scientometric studies (Liu et al. 2011, Cao et al. 2012) the term: (i) "collaborative publication" was assigned to papers with two or more authors, (ii) "single country publication" if the researchers were from the same country, (iii) "internationally collaborative publication" to those papers that were coauthored by researchers from multiple countries, (iv) " single institute publication" if the researchers were from the same institute, and (v) " inter-institutionally collaborative publication" if the authors were from different institutes.

\section{RESULTS}

A total of 107 papers on L. fortunei research were contained within the ISI web database between 1982 and 2012. From 1982 to 1998, few papers were published and for many years, no papers appeared on the subject. The regression tree analysis partitioned the predictor variable (i.e., year of publication) into two periods: before and after
2004.5. The period from 1982 to 2004 corresponds to the period with a low and relatively constant production of papers on L. fortunei. The second period (2005 to 2012) showed an increase in the number of papers published (Figure 1).

Papers on L. fortunei appeared in 60 journals, although $39.25 \%(\mathrm{~N}=42)$ of these contained only one paper and $18.69 \%(\mathrm{~N}=10)$ contained only two papers. The eight journals that published more than three papers on $L$. fortunei accounted for $42.06 \%$ (45 papers) of the total number (Figure 2). The journal Hydrobiologia published 10 papers, followed by Biofouling (seven papers) and the Brazilian Journal of Biology and the Journal of Shellfish Research (six papers, each). The number of journals considered, increased over the years $(z=6.822, P<0.001, \mathrm{~N}=20)$.

Thirty-three papers $(30.84 \%)$ received only between one and four citations, whereas 23 papers $(21.50 \%)$ were never cited (Figure 3a). The mostcited article was by Ricciardi (1998), which received 45 citations. Other heavily cited papers were by Villela et al. (2006), Boltovskoy et al. (2006) (39 citations, each), Darrigran et al. (1998) (38 citations), and Karatayev et al. (2007b) (37 citations). The paper by Karatayev et al. (2007a) figured among the most cited after standardizing the number of citations by the year of publication (i.e., the number of citations divided by the number of years since their publication) (Figure $3 b$ ). There was a difference in citation between types of papers $(F=14.68, P<0.001, \mathrm{~N}=107)$; reviews received more citations than other types of papers.

Field-observational studies were the most often conducted, appearing in 43 papers $(40.18 \%)$, followed by laboratory-experimental studies (30 papers, or $28.03 \%$ ), field-experimental studies (21 papers, or $19.62 \%$ ), and others (13 papers, or $12.14 \%$ ).

Ten countries published papers on L. fortunei (Table I). The greatest number of articles was published from Argentina (56.07\% or 60 out of 107 papers), followed by Brazil (30 papers, or 


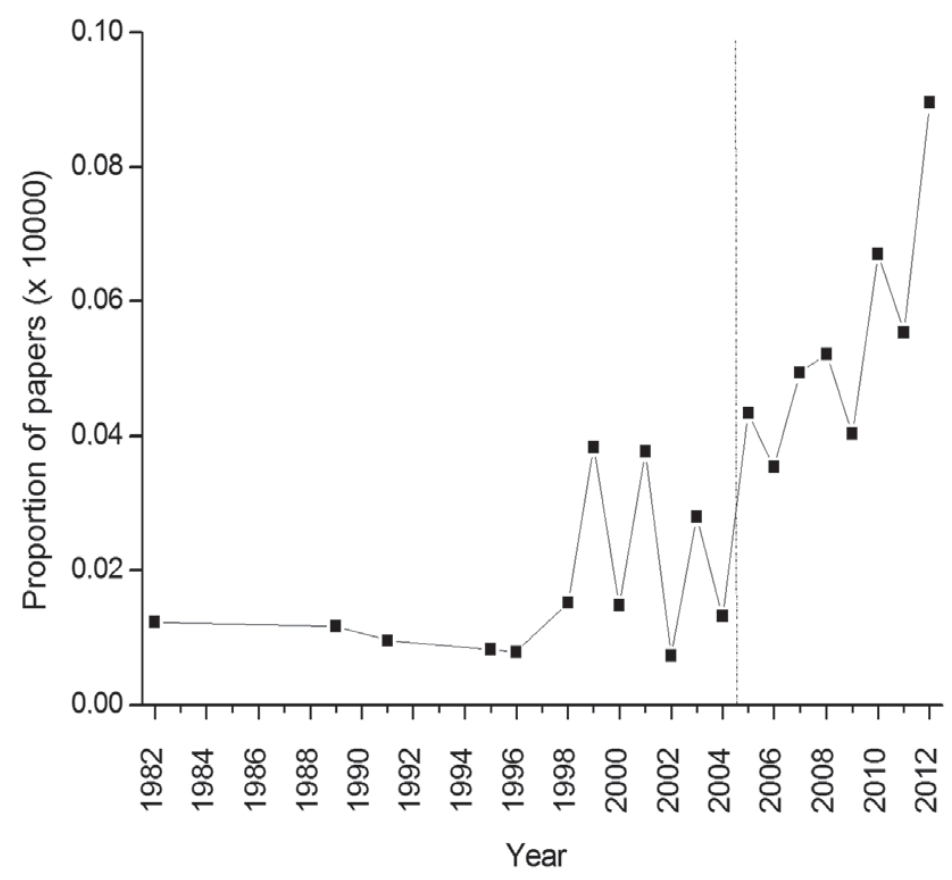

Fig. 1 - Proportion of papers (x 10000) on Limnoperna fortunei research in relation to the total number of papers published from 1982 to 2012, indexed by the Institute for Scientific Information (ISI). The dashed line indicates the year (2004.5) in which the regression tree partitioned the data in two segments.

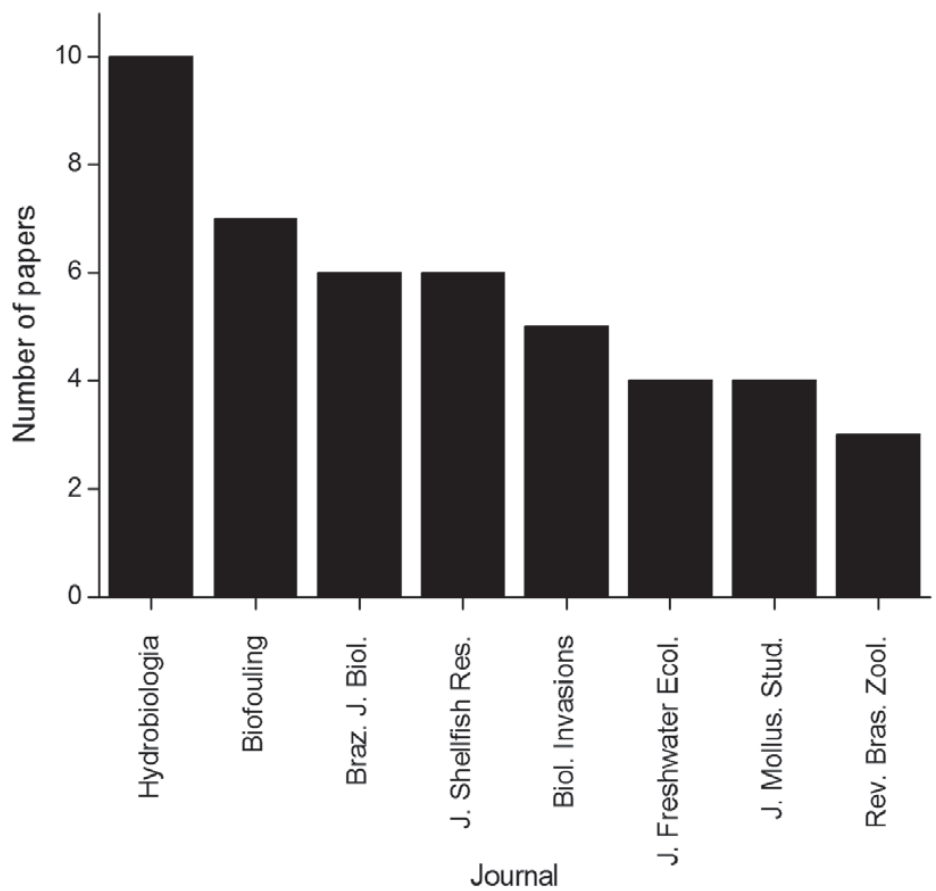

Fig. 2 - Journals that published more than three papers on Limnoperna fortunei indexed by the ISI from 1882 to 2012 . Braz. J. Biol. = Brazilian Journal of Biology, J. Shellfish Res. = Journal of Shellfish Research, Biol. Invasions = Biological Invasions, J. Freshwater Ecol. = Journal of Freshwater Ecology, J. Mollus. Stud. = Journal of Molluscan Studies, and Rev. Bras. Zool. = Revista Brasileira de Zoologia (currently, Zoologia). 
(a)

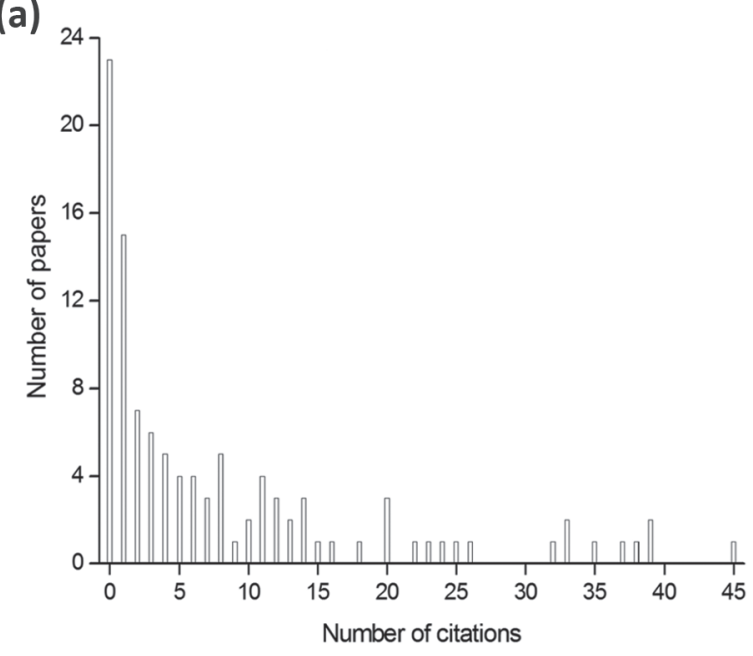

(b)

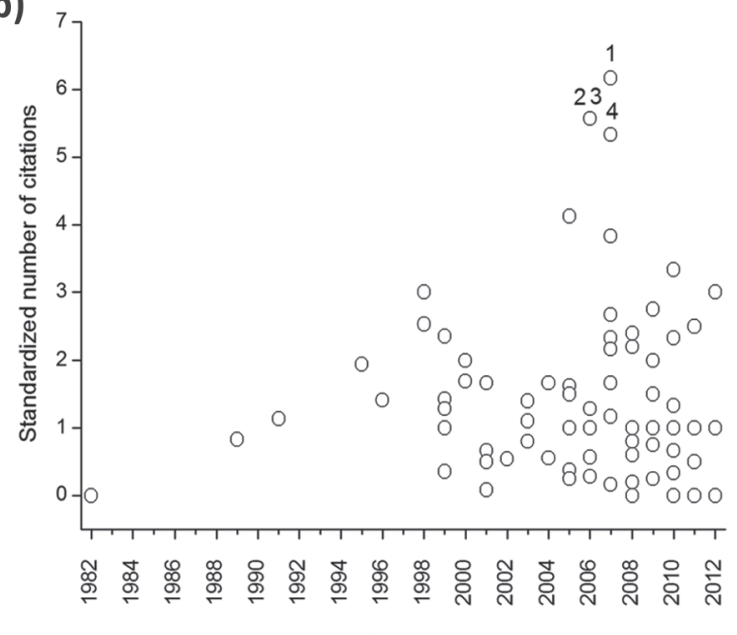

Year

Fig. 3 - Number of papers in relation to the number of citations received (a) and temporal variation in the standardized (number of citations divided by the number of years since the papers was published) number of citations received by each paper (b). Number in (b) are: 1 = Karatayev et al. (2007b); 2 = Villela et al. (2006); 3 = Boltovskoy et al. (2006); 4 = Karatayev et al. (2007a).

TABLE I

Countries that published on Limnoperna fortunei with the number of papers, single country publication, and internationally collaborative publication during the period of 1982-2012.

\begin{tabular}{cccc}
\hline Country & TP & SP & CP \\
\hline Argentina & 60 & 46 & 14 \\
Brazil & 30 & 21 & 9 \\
Japan & 14 & 14 & 0 \\
United States & 11 & 1 & 10 \\
Canada & 4 & 1 & 3 \\
Germany & 3 & 0 & 3 \\
Hong Kong & 2 & 1 & 1 \\
United Kingdom & 2 & 1 & 1 \\
Uruguay & 2 & 2 & 0 \\
Ireland & 1 & 0 & 1 \\
\hline
\end{tabular}

TP, total papers; SP, single country publication; $\mathrm{CP}$, internationally collaborative publication.

$28.03 \%$ of the total 107 papers), and Japan (14 papers, or $13.08 \%$ of the total 107 papers). The number of single country publications was higher than that of internationally collaborative publications $(t=4.1474, P=0.0005472, \mathrm{~N}=20)$. Argentina was the single country responsible for the most papers (46, or $42.98 \%$ of the total 107 papers) and for internationally collaborative papers $(14$, or $13.08 \%$ of the total 107 papers). Japan had no internationally collaborative papers and the United States of America (USA) was the country with the second highest number of internationally collaborative papers (Table I) and its major collaborators were Argentina and Brazil.

A total of 207 authors contributed to studies on L. fortunei, although from 146 authors who (co) authored at least one $L$. fortunei paper, 58 or $28.02 \%$ contributed to fewer than eight papers, whereas the top three or $3.86 \%$ authors produced 61 or $57 \%$ of the total papers. The most productive authors in L. fortunei research were Boltovskoy and Darrigran with 22 papers each, followed by Cataldo 
with 17 papers (Table II). The six most productive authors tended to cooperate with a relatively small group of co-authors. For example, Mansur and Sylvester had a mean of 2.42 and 2.37 co-authors on their papers, respectively (Table II). The mean number of authors per paper for all $L$. fortunei papers \pm S.E. was $3.85 \pm 0.37$ and the number of authors per paper did not increase during the period studied $(z=0.597, P=0.550, \mathrm{~N}=107)$.

TABLE II

The six most productive authors that published on Limnoperna fortunei with the number of papers, collaborated publications, co-authorships during the period of 1982-2012.

\begin{tabular}{cccc}
\hline Author & TP & CP & CO \\
\hline Boltovskoy, D & 22 & 22 & 25 \\
Darrigran, G & 22 & 22 & 35 \\
Cataldo, DH & 17 & 17 & 23 \\
Damborenea, MC & 8 & 8 & 11 \\
Sylvester, F & 8 & 8 & 19 \\
Mansur, MCD & 7 & 7 & 17 \\
\hline
\end{tabular}

$\mathrm{TP}$, total papers; $\mathrm{CP}$, collaborated publications; $\mathrm{CO}$, co-authorships.

Limnoperna fortunei studies were performed in 70 research institutions, 38 or $54.28 \%$ of which published only one paper and 23 or $32.85 \%$ published fewer than four papers. The nine research institutions that published more than five papers on L. fortunei accounted for $12.85 \%$ of the total (Table III). The Consejo Nacional de Investigaciones Cientificas y Tecnicas led institutional productivity with 46 papers, followed by the Museo Argentino de Ciencias Naturales "Bernardino Rivadavia" with 28 papers, the Universidad de Buenos Aires with 24 papers, and the Universidad Nacional de La Plata with 18 papers. The number of inter-institutional collaborations was higher than that of single institute publications $(t=-2.8613, P=0.0099, \mathrm{~N}=20)$.

\section{DISCUSSION}

This scientometric study showed an increase in the number of papers on L. fortunei over time, especially in the eight years from 2005-2012, probably due to increasing interest in invasive species in recent decades (Lowry et al. 2013). Additionally, the serious ecological and economic impact caused by the species (Boltovskoy et al. 2006, Karatayev et al. 2007a) has certainly contributed to the growth of studies, because, according to Pysek et al. (2008), the impact of an invasive species determines whether it is studied. However, the number of studies on L. fortunei

TABLE III

The nine most productive research institutions that published on Limnoperna fortunei with the number of papers, single institute publication, and inter-institutional collaborative publication during the period of 1982-2012.

\begin{tabular}{lccc}
\hline \multicolumn{1}{c}{ Institute } & TP & SP & CP \\
\hline Consejo Nacional de Investigaciones Cientificas y Tecnicas, Argentina & 46 & 2 & 44 \\
Museo Argentino de Ciencias Naturales "Bernardino Rivadavia”, Argentina & 25 & & 25 \\
Universidad de Buenos Aires, Argentina & 24 & & 24 \\
Universidad Nacional de La Plata, Argentina & 18 & 2 & 16 \\
Universidade Federal do Rio Grande do Sul, Brazil & 7 & 7 \\
Universidade Federal do Paraná, Brazil & 7 & 2 & 5 \\
Gifu University, Japan & 6 & & 6 \\
Shinshu University, Japan & 6 & 1 & 5 \\
Embrapa Pantanal, Brazil & 5 & & 5 \\
\hline
\end{tabular}

TP, total papers; SP, single institute publication; CP, inter-institutional collaborative publication. 
has increased much less than that on other freshwater invasive bivalves. For instance, Sousa et al. (2013) conducted a scientometric study on freshwater invasive bivalves using publications of the period 1980-2010 and found more studies with D. polymorpha, C. fluminea, and D. bugensis than for L. fortunei.

The papers on L. fortunei were published in many journals and this number increased throughout the studied period. This pattern suggests that studies on L. fortunei have been performed in several research areas, beyond biology or ecology. For instance, some papers were published in journals of engineering and water resources (e.g., Environmental Science and Technology and the Journal of the American Water Works Association), since the species had an economic impact to manmade structures (Mansur et al. 2003). The journal that published the most papers on golden mussel was Hydrobiologia and this journal was also the favorite for studies on macrophytes in the Neotropics (Padial et al. 2008), following the general pattern noted by Hendriks and Duarte (2008) and Melo et al. (2006). This pattern is probably related to the fact that Hydrobiologia publishes papers in all sub-fields of Limnology, with no bias regarding organism (Melo et al. 2006).

Citation frequency is usually used to quantify the relative importance of a paper (Garfield 1972). In this study, 51 papers were cited more than five times, which does not support the pattern suggested by Garfield (2006), in which most published papers are never cited or cited only a few times. Similarly, in a recent scientometric study, Barbosa et al. (2012) showed that $60 \%$ of the papers on the use of ecological niche models to predict the distribution of invasive species were cited more than five times. Among the most-cited papers, that by Ricciardi (1998), which is a review of the biology and invasion history of L. fortunei in Asia (Hong Kong, Japan, and Taiwan) and South America (Argentina and Uruguay), evaluates its potential range of expansion into North America. The other highly cited papers include three reviews (Karatayev et al. 2007a, b, Boltovskoy et al. 2006), which were published years after the growing interest in studies on L. fortunei as well as papers that evaluated the potential of $L$. fortunei as a biomonitor organism for the detection of genotoxicity in polluted water (Villela et al. 2006) and the impact caused by the species on the composition of the native fauna in Rio de la Plata, Argentina (Darrigran et al. 1998). According to Ruiz et al. (2009), reviews are usually more cited than original papers, which was the case here, following the general pattern noted by Sainte-Marie (2010).

Field-observational studies were the preferable approach in studies on L. fortunei. Similarly, in a recent systematic review on biological invasions, Lowry et al. (2013) showed that almost half of the papers were field-observational studies. However, other types of studies were important, especially those using modeling techniques. Modeling studies have been applied to predict the potential distribution of invasive species (Jiménez-Valverde et al. 2011) and therefore, are also essential for future preventative actions against L. fortunei (Barbosa and Melo 2009, Oliveira et al. 2010a), since once the species is present in the environment, it is extremely difficult to eradicate (Oliveira et al. 2006).

Argentina, Brazil and Japan were the countries that published the most papers. This is probably due to the problems caused by L. fortunei in man-made structures in Argentina (Darrigran and Damborenea 2005, Boltovskoy et al. 2006), Brazil (Mansur et al. 2003), and Japan (Magara et al. 2001, Matsui et al. 2002). Moreover, Qiu and Chen (2009) used publications from the period of 1991-2007 to perform a bibliometric study of all biological invasion-related publications and showed that Argentina, Brazil, and Japan were among the 15 countries that published papers on biological invasions with the highest frequency. According to May (1997), this high scientific production is 
associated with economic development. In South America, Argentina and Brazil are among the countries with the largest economies (World Bank 2013). Additionally, Speziale et al. (2012) conducted a study to analyze the temporal trends of scientific research on non-native species in South America using publications of the period of 1961-2010, and Argentina and Brazil were the most productive countries. The low representation and/or lack of studies in countries invaded by $L$. fortunei might have several explanations, such as fewer resources for scientific studies and language barriers in countries in South America (see Speziale et al. 2012 for more explanations). The lack of studies within the native region of $L$. fortunei is notable, because this knowledge is essential to identify ways to mitigate the main problems caused by the species (Sousa et al. 2013).

Increasing international collaboration over time is a general trend across all countries and scientific fields (Abt 2007). In this study, the frequency of single country publications was higher than that of international collaborations. This suggests that academic communities of $L$. fortunei research are not internationally connected. For instance, Japan has no international collaborative papers, the same pattern noted by Qiu and Chen (2009) in biological invasion research. Moreover, the observed level of international cooperation on $L$. fortunei is much lower than that for the general field of biological invasions (57\% across countries; Qiu and Chen 2009).

L. fortunei is not present in the USA, which had the second highest number of international collaborative papers, mainly together with Argentina and Brazil, both countries which are invaded by L. fortunei. This might be attributable to the high scientific production of the USA worldwide (Fazey et al. 2005). Furthermore, the USA is on the same continent as its main collaborators (some countries essentially collaborate only with countries that are close geographically) (Katz 1994), which probably facilitates cooperation (Leta and Chaimovich
2002). Padial et al. (2008) also showed that the USA cooperated the most in studies of aquatic macrophytes published by Neotropics. In parallel, using modeling techniques, Oliveira et al. (2010a) demonstrated the forecasts of the potential distribution of $L$. fortunei in three major North American river systems (Mississippi, Colorado, and Rio Grande).

A small group of authors has contributed a substantial amount of papers on $L$. fortunei. This trend is not unique to studies of $L$. fortunei. Liu et al. (2011) showed that the most productive authors published $50.1 \%$ of the total papers on biodiversity. The most productive authors and research institutions on $L$. fortunei were from Argentina, Brazil and Japan. This domination of publication is not surprising, since these were the countries that published the most on this species.

In this study, the most productive authors tended to cooperate with a relatively small group of co-authors, the number of author per paper did not increase over the studied years and inter-institutional collaborations were more prevalent than single institute publications. These results suggest that $L$. fortunei has been studied by research teams composed of different research institutions within a single country. One possible explanation for this is the pressure from funding agencies and institutions of each country to increase research via interinstitutional collaborations and institutes might be developing into larger centers and labs, with greater investment. Additionally, previous scientometric studies showed that several authors tend to cooperate with a small group of collaborators (Qiu and Chen 2009, Liu et al. 2011) and that inter-institutional collaborations are more prevalent than international collaborations (Liu et al. 2011). The increase in the number of authors per paper over time is a global trend in science (Porter and Rafols 2009), however, this was not observed in this study, although, the mean number of authors per paper was higher 
than for the field of invasive species research in general (3.2; Qiu and Chen 2009).

In summary, this scientometric analysis showed an increase in the number of papers on L. fortunei over time, especially in the last eight years of the studied period. However, some important gaps need to be addressed, such as the relatively small number and/or lack of studies conducted in the native countries or those invaded by L. fortunei, such as Bolivia, Hong Kong, Uruguay, Paraguay, and Taiwan, and the low number of internationally collaborative publications, as well as the lack of studies from international cooperation between native countries and those invaded by L. fortunei. However, it is notable that the low representation of studies from countries invaded by L. fortunei in this study does not necessarily represent a total absence of studies, but might mean that such studies are only available in other small or regional databases. L. fortunei is one of the worst aquatic invasive species due to its serious ecological and economic impact (Mansur et al. 2003). In addition, models based on the ecological niche have been used to predict the spread of L. fortunei (Kluza and McNyset 2005, Oliveira et al. 2010a, b). For instance, the global model created by Kluza and McNyset (2005) has shown that $L$. fortunei can potentially colonize regions of Africa, Asia, Europe, North America, South America, and Central America. Whereas eradication of the species is extremely difficult (Oliveira et al. 2006), measures to control its spread are important. Thus, future studies via international collaboration, together with cooperative studies between native countries and those invaded by the species, are of considerable importance to mitigate the main problems caused by L. fortunei.

\section{ACKNOWLEDGMENTS}

The research was supported by Conselho Nacional de Desenvolvimento Científico e Tecnológico (CNPq) (Post-Doc scholarship \#246048/2012-3).

\section{RESUMO}

Limnoperna fortunei (golden mussel) é um bivalve de água doce nativo do sudeste da Ásia, mas está se tornando uma espécie invasora em diversos ecossistemas aquáticos do mundo. Neste estudo, uma análise cienciométrica foi realizada para identificar padrões, tendências e lacunas do conhecimento para esta espécie invasora. Uma pesquisa da literatura publicada foi realizada utilizando a base de dados Thomson Institute for Scientific Information (ISI). Foram encontrados 107 artigos publicados entre 1982 e 2012 , em 60 periódicos. O número de artigos sobre L. fortunei tem aumentado ao longo dos anos, especialmente nos últimos oito anos do período de estudo. Argentina, Brasil e Japão são os países que mais publicaram artigos sobre o bivalve invasor. A maioria dos artigos foi estudos de campo-observacional. Entre algumas lacunas importantes que precisam ser abordadas são o número relativamente pequeno e/ou falta de estudos realizados em países nativos e invadidos por L. fortunei, a falta de publicações colaborativas internacionais entre estes países, bem como um número baixo de estudos colaborativos internacionais.

Palavras-chave: invasões biológicas, mexilhão dourado, produção científica, análise cienciométrica.

\section{REFERENCES}

Авт HA. 2007. The future of single-authored papers. Scientometrics 73: 353-358.

Barbosa FG AND Melo AS. 2009. Modelo preditivo de sobrevivência do mexilhão dourado (Limnopena fortunei) em relação a variações de salinidade na Laguna dos Patos, RS, Brasil. Biota Netropica 9: 407-412.

BARBOSA FG, SCHNECK F AND MELO AS. 2012. Use of ecological niche models to predict the distribution of invasive species: a scientometric analysis. Braz J Biol 72: 821-829.

Boltovskoy D, Correa N, CATAldo D ANd Sylvester F. 2006. Dispersion and ecological impact of the invasive freshwater bivalve Limnoperna fortunei in the Rio de la Plata watershed and beyond. Biol Invasions 8: 947-963.

Boltovskoy D, KaratayeV A, Burlakova L, Cataldo D, KaratayeV V, Sylvester F AND Marinelarena A. 2009. Significant ecosystem-wide effects of the swiftly spreading invasive freshwater bivalve Limnoperna fortunei. Hydrobiologia 636: 271-284. 
Brugnoli E, Clemente J, Boccardi L, Borthagaray A AND SCARABINO F. 2005. Golden mussel Limnoperna fortunei (Bivalvia: Mytilidae) distribution in the main hydrographical basins of Uruguay: update and predictions. An Acad Bras Cienc 77: 235-244.

CAO XF, HUANG Y, WANG J AND LUAN SJ. 2012. Research status and trends in limnology journals: a bibliometric analysis based on SCI database. Scientometrics 92: 735-746.

CApítoli RR, Colling LA AND Bemvenuti CE. 2008. Cenários de distribuição do mexilhão dourado Limnoperna fortunei (Mollusca - Bivalvia) sob distintas condições de salinidade no complexo Lagunar Patos-Mirim, RS Brasil. Atlântica 30: 35-44.

Clavero M AND GARCIA-Berthou E. 2005. Invasive species are a leading cause of animal extinctions. Trends Ecol Evol 20: 110.

Crawley MJ. 2007. The R Book. J Wiley \& Sons Ltd, 950 p.

DARRIGRAN G AND DAMBORENEA C. 2005. A bioinvasion history in South America. Limnoperna fortunei (Dunker, 1857), the golden mussel. Am Malacol Bull 20: 105-112.

DARrigran G, DAmborenEA C AND GRECO N. 2007. An evaluation pattern for antimacrofouling procedures: Limnoperna fortunei larvae study in a hydroelectric power plant in South America. AMBIO 36: 575-579.

DARRIGRAN G AND MANSUR MCD. 2006. Distribución, abundancia y dispersión. In: DARRIGRAN G AND DAMBORENEA C (Eds), Bio-invasión del mejillón dorado en el continente americano. Edulp, La Plata, Argentina, p. 93-110.

DARRIGRAN G AND MANSUR MCD. 2009. Introdução e dispersão do Limnoperna fortunei. In: DARRIGRAN G AND DAMBORENEA C (Eds), Introdução à Biologia das Invasões. O mexilhão dourado na América do Sul: biologia, dispersão, impacto, prevenção e controle. Cubo Editora. São Carlos, Brasil, p. 89-109.

DARrigran G, MARtin SM, GULLO B AND ARMENDARIZ L. 1998. Macroinvertebrates associated with Limnoperna fortunei (Dunker, 1857) (Bivalvia, Mytilidae) in Rio de la Plata, Argentina. Hydrobiologia 367: 223-230.

DARRIGRAN GAND PASTORINO G. 1995. The recent introduction of a freshwater asiatic bivalve Limnoperna fortunei (Mytilidae) into South America. The Veliger 32: 171-175.

DE'Ath G AND FABRicius KE. 2000. Classification and regression trees: a powerful yet simple technique for ecological data analysis. Ecology 81: 3178-3192.

Elliott P, Aldridge DC, Moggridge GD AND ChIPPS M. 2005. The increasing effects of zebra mussels on water installations in England. Water Environ J 19: 367-375.

FAZEY I, FISCHER J AND LINDENMAYER DB. 2005. Who does all the research in conservation biology? Biodivers Conserv 14: $917-934$.

GARFIELD E. 1972. Citation analysis as a tool in journal evaluation - journals can be ranked by frequency and impact of citations for science policy studies. Science 178: 471-479.

GARFIELD E. 2006. The history and meaning of the journal impact factor. JAMA - J Am Med Assoc 295: 90-93.
Gotelli NJ AND Ellison AM. 2012. A Primer of Ecological Statistics. $2^{\text {nd }}$ ed., Sinauer Associates, Inc., Massachusetts, $614 \mathrm{p}$.

HENDRIKS IE AND DUARTE CM. 2008. Allocation of effort and imbalances in biodiversity research. J Exp Mar Biol Ecol 1: $15-20$

HoOD WW AND WILSONCS. 2001. The literature of bibliometrics, scientometrics and informetrics. Scientometrics 52: 921-314.

KaRATAYEV AY, BOLTOVSKOY D, PADILLADKAND BURLAKOVA LE. 2007a. The invasive bivalves Dreissena polymorpha and Limnoperna fortunei: parallels, contrasts, potential spread and invasion impacts. J Shellfish Res 26: 205-213.

KaratayeV AY, Padilla DK, Minchin D, Boltovskoy D AND BURLAKOVA LE. 2007b. Changes in global economies and trade: the potential spread of exotic freshwater bivalves. Biol Invasions 9: 161-180.

KATZ JS. 1994. Geographical proximity and scientific collaboration. Scientometrics 31: 31-43.

KIMURA T. 1994. The earliest record of Limnoperna fortunei (Dunker) from Japan. Chiribotan 25: 34-35.

KLUZA DA AND MCNYSET M. 2005. Ecological niche modeling of aquatic invasive species. Aquat Invaders 16: 1-7.

JiMÉNEZ-VALVERde A, PETERSON AT, SOBERÓN J, OVERTON JM, ARAGÓN P AND LOBO JM. 2011. Use of niche models in invasive species risk assessments. Biol Invasions 13: 2785-2797.

Leta J AND Chaimovich H. 2002. Recognition and international collaboration: the Brazilian case. Scientometrics 53: 325-335.

LIU XJ, ZHANG LA AND HoNG S. 2011. Global biodiversity research during 1900-2009: a bibliometric analysis. Biodivers Conserv 20: 807-826.

LOWRY E, ROLLINSON EJ, LAYBOURN AJ, SCOTT TE, AIELloLAMMENS ME, GRAY SM, MiCKLEY J AND GUREVITCH J. 2013. Biological invasions: a field synopis, systematic review, and database of the literature. Ecol Evol 3: 182-196.

LUCY FE, KARATAYEV AY AND BURLAKOVA LE. 2012. Predictions for the spread, population density, and impacts of Corbicula fluminea in Ireland. Aquat Invasions 7: 465-474.

MAGARA Y, MATSUI Y, Goto Y AND YUASA A. 2001. Invasion of the non-indigenous nuisance mussel, Limnoperna fortunei, into water supply facilities in Japan. J Water Supply Res Technol-AQUA 50: 113-124.

MANSUR MCD, SANTOS CP, DARRIGRAN G, HEYDrich I, CALLIL CT AND CARDOSO FR. 2003. Primeiros dados qualiquantitativos do mexilhão-dourado, Limnoperna fortunei (Dunker), no Delta do Jacuí, no Lago Guaíba e na Laguna dos Patos, Rio Grande do Sul, Brasil e alguns aspectos de sua invasão no novo ambiente. Rev Bras Zool 20: 75-84.

Matsui Y, Nagaya K, Funahashi G, Goto Y, Yuasa A, Yamamoto H, OHKAWA K AND Magara Y. 2002. Effectiveness of antifouling coatings and water flow in controlling attachment of the nuisance mussel Limnoperna fortunei. Biofouling 18: 137-148.

MAY RM. 1997. The scientific wealth of nations. Science 275: 793-796. 
Melo AS, Bini LM AND CARVAlHo P. 2006. Brazilian articles in international journals on limnology. Scientometrics 67: 187-199.

MORTON B. 1977. The population dynamics of Limnoperna fortunei (Dunker, 1857) (Bivalvia: Mytilacea) in Plover Cove reservoir, Hong Kong. Malacologia 16: 165-182.

OLIVEIRA MD, HAMILTON SK, CALHEIROS DF, JACOBI CM AND LATINI RO. 2010b. Modelling the potential distribution of the invasive golden mussel Limnoperna fortunei in the Upper Paraguay River system using limnological variables. Braz J Biol 70: 831-840.

OliveIRA MD, HAMILTON SK AND JACOBI CM. 2010a. Forecasting the expansion of the invasive golden mussel Limnoperna fortunei in Brazilian and North American rivers based on its occurrence in the Paraguay River and Pantanal wetland of Brazil. Aquat Invasions 5: 59-73.

OliveIra MD, TAKEDA AM, De BARros LF, BARBosa DS AND DE RESENDE EK. 2006. Invasion by Limnoperna fortunei (Dunker, 1857) (Bivalvia, Mytilidae) of the Pantanal wetland, Brazil. Biol Invasions 8: 97-104.

PAdial AA, BINI LM AND THOMAZ SM. 2008. The study of aquatic macrophytes in Neotropics: a scientometrical view of the main trends and gaps. Braz J Biol 68: 1051-1059.

PAStorino G, DARrigran G, MARTIN S AND LUNASCHI L. 1993. Limnoperna fortunei (Dunker 1857) (Mytilidae), nuevo bivalvo invasor en aguas del Rio de La Plata. Neotropica 39: 171-175.

Pejchar L AND MoOney HA. 2009. Invasive species, ecosystem services and human well-being. Trends Ecol Evol 24: 497-504.

PIMENTEL D ET AL. 2001. Economic and environmental threats of alien plant, animal, and microbe invasions. Agr Ecosyst Environ 84: 1-20.

PORTER AL AND RAFOLS I. 2009. Is science becoming more interdisciplinary? Measuring and mapping six research fields over time. Scientometrics 81: 719-745.

PyseK P, Richardson DM, PERgL J, Jarosik V, SiXtova Z AND WEBER E. 2008. Geographical and taxonomic biases in invasion ecology. Trends Ecol Evol 23: 237-244.

QIU H AND CHEN YF. 2009. Bibliometric analysis of biological invasions research during the period of 1991 to 2007. Scientometrics 81: 601-610.
R Development Core Team. 2013. R: A language and environment for statistical computing. R Foundation for Statistical Computing, Vienna, Austria. ISBN. 3-90005107-0, URL http://www.R-project.org/.

RICCIARDI A. 1998. Global range expansion of the Asian mussel Limnoperna fortunei (Mytilidae): Another fouling threat to freshwater systems. Biofouling 13: 97-106.

RICHARDSON D AND PYSEK P. 2008. Fifty years of invasion ecology - the legacy of Charles Elton. Divers Distrib 14: 161-168.

RUIZ MA, GRECO OT AND BRAILE DM. 2009. Fator de impacto: importância e influência no meio editorial, acadêmico e científico. Rev Bras Hematol Hemoter 31: 355-360.

SAINTE-MARIE B. 2010. The first 30 years of the journal of crustacean biology - a bibliometric study. J Crust Biol 30: 541-549.

SPEZIALE KL, KARINA L, LAMBERTUCCI SA, CARRETE M AND TELLA JL. 2012. Dealing with non-native species: what makes the difference in South America? Biol Invasions 14: 1609-1621.

STRAYER D. 2010. Alien species in fresh waters: ecological effects, interactions with other stressors, and prospects for the future. Freshwater Biol 55: 152-174.

SOKAL RR AND ROHLF FJ. 1994. Biometry - The principles and pratice of statistics in biological research. $3^{\text {rd }}$ ed., W. H. Freeman and Company, New York, 776 p.

SOUSA R, NOVAIS A, COSTA RAND STRAYER DL. 2013. Invasive bivalves in fresh waters: impacts from individuals to ecosystems and possible control strategies. Hydrobiologia 735(1): 233-251.

THERnEAU T, ATKINSON B AND Ripley B. 2012. rpart: Recursive Partitioning. R package version 4.1-0.

VAN RAAN AFJ. 1997. Scientometrics: State-of-the-Art. Scientometrics 38: 205-218.

VILLELA IV, DE OLIVEIRA IM, DA SILVA J AND HENRIQUES JAP. 2006. DNA damage and repair in haemolymph cells of golden mussel (Limnoperna fortunei) exposed to environmental contaminants. Mutat Res-Gen Tox En 605: 78-86.

WORLD BANK. 2013. World development indicators database. Available from: http://data.worldbank.org. Acessed 2 April 2013. 
